\title{
Late Silurian deformation in the Kysogóry Region of the Holy Cross Mountains revisited: restoration of a progressive Caledonian unconformity in the Klonów Anticline and its implications for the kinematics of the Holy Cross Fault (central Poland)
}

\author{
Łukasz GĄGAŁA ${ }^{1,2, *}$ \\ 1 Georex SA, 145, rue Michel Carré, 95100 Argenteuil, France \\ 2 Polish Academy of Sciences, Institute of Geological Sciences, Twarda 51/55, 00-818 Warszawa, Poland
}

Gągała, Ł., 2015. Late Silurian deformation in the Łysogóry Region of the Holy Cross Mountains revisited: restoration of a progressive Caledonian unconformity in the Klonów Anticline and its implications for the kinematics of the Holy Cross Fault (central Poland). Geological Quarterly, 59 (3): 441-456, doi: 10.7306/gq.1222

\begin{abstract}
The Klonów Anticline is located in the western outskirts of the Łysogóry Region of the Holy Cross Mountains. A fresh look onto the cartographic evidence suggests that this structure shows the key characteristics of a progressive unconformity. This becomes evident when compared to the classical example of the Sant Llorenç de Morunys Anticline (eastern Pyrenees, Spain). The geometry of the unconformity requires a phase of thrusting or reverse faulting along the Holy Cross Fault in the latest Silurian-earliest Devonian (Late Caledonian deformation) followed by Variscan thin-skinned thrusting. Thick- and thin-skinned kinematic scenarios for the latest Silurian-earliest Devonian deformation of the Łysogóry Region are explored.
\end{abstract}

Key words: Caledonian and Variscan tectonics, tectonics-sedimentation interplay, triangle zone, cross-section restoration.

INTRODUCTION

The Łysogóry and Małopolska blocks are situated outboard of the southwestern margin of the East European Craton (EEC; Fig. 1). These belong to an assemblage of Neoproterozoic-Paleozoic tectonic units, which stretches along the southwestern margin of the Archean to Mid-Proterozoic EEC, and which is often named the Trans-European Suture Zone (TESZ) (e.g., Berthelsen, 1993; Pharaoh, 1999). Their local (Baltic) or exotic (Pan-African) provenance is still a matter of debate (e.g., Nawrocki et al., 2007; Krawczyk et al., 2008; Kroner et al., 2008; Narkiewicz et al., 2015). The Łysogóry and Małopolska blocks have passed through a prolonged NeoprotorezoicPaleogene depositional and tectonic history that embraced formation of successive sedimentary basins punctuated by phases of tectonic shortening and wrenching. As suggested by the recent deep reflection seismic survey POLCRUST-01 (Malinowski et al., 2013), the Łysogóry Block and at least the northern part of the Małopolska Block are floored by the crust of the EEC (Fig. 1B).

The Łysogóry and Małopolska blocks are largely concealed beneath Permo-Mesozoic sediments of the Polish Basin and Miocene sediments of the Carpathian Foredeep. Their pre-

\section{*E-mail: Igagala@georex.com}

Received: July 9, 2014; accepted: January 19, 2015; first published online: February 18, 2015
Permian basement crops out only in the Holy Cross Mts. (HCM) (Fig. 1A). This Paleozoic inlier exposes a contact between the Łysogóry and Małopolska blocks, which is defined by the Holy Cross Fault (HCF). The HCM is the only window into the structure of the Polish segment of the TESZ and has therefore been the subject of numerous studies (e.g., Lewandowski, 1993; Mizerski, 1995; elaźniewicz, 1998; Lamarche et al., 1999, 2003; Nawrocki, 2000; Porębska, 2002; Belka et al., 2002; Konon, 2006, 2007; Nawrocki and Poprawa, 2006; Poprawa, 2006a, b; Schätz et al., 2006; Nawrocki et al., 2007; ylińska and Masiak, 2007; Kozłowski, 2008; Kozłowski et al., 2014).

The Paleozoic exposures of the HCM are divided by the HCF into the Łysogóry Region in the north and the Kielce Region in the south (Czarnocki, 1936; Fig. 2, inset map). These represent the only outcropping fragments of the Łysogóry and Małopolska blocks. The Łysogóry and Kielce regions display stratigraphic and structural differences that have triggered a debate as to whether the Łysogóry and Małopolska blocks shared a common pre-Devonian tectonic evolution or evolved independently and were juxtaposed along the HCF during Early Paleozoic wrenching (Brochwicz-Lewiński et al., 1984; Po aryski, 1990; Lewandowski, 1993, 1994; Tomczykowa and Tomczyk, 2000; Nawrocki and Poprawa, 2006; Poprawa, 2006b; Nawrocki et al., 2007; Kozłowski, 2008; Kozłowski et al., 2014). One of the lines of reasoning that supports a decoupled structural evolution of these two tectonic units is a contrast between a nearly continuous Late Silurian-Early Devonian sedimentary succession in the Łysogóry Region and a deeply incised baseEmsian (Caledonian) unconformity in the Kielce Region (e.g., Kozłowski et al., 2014). 


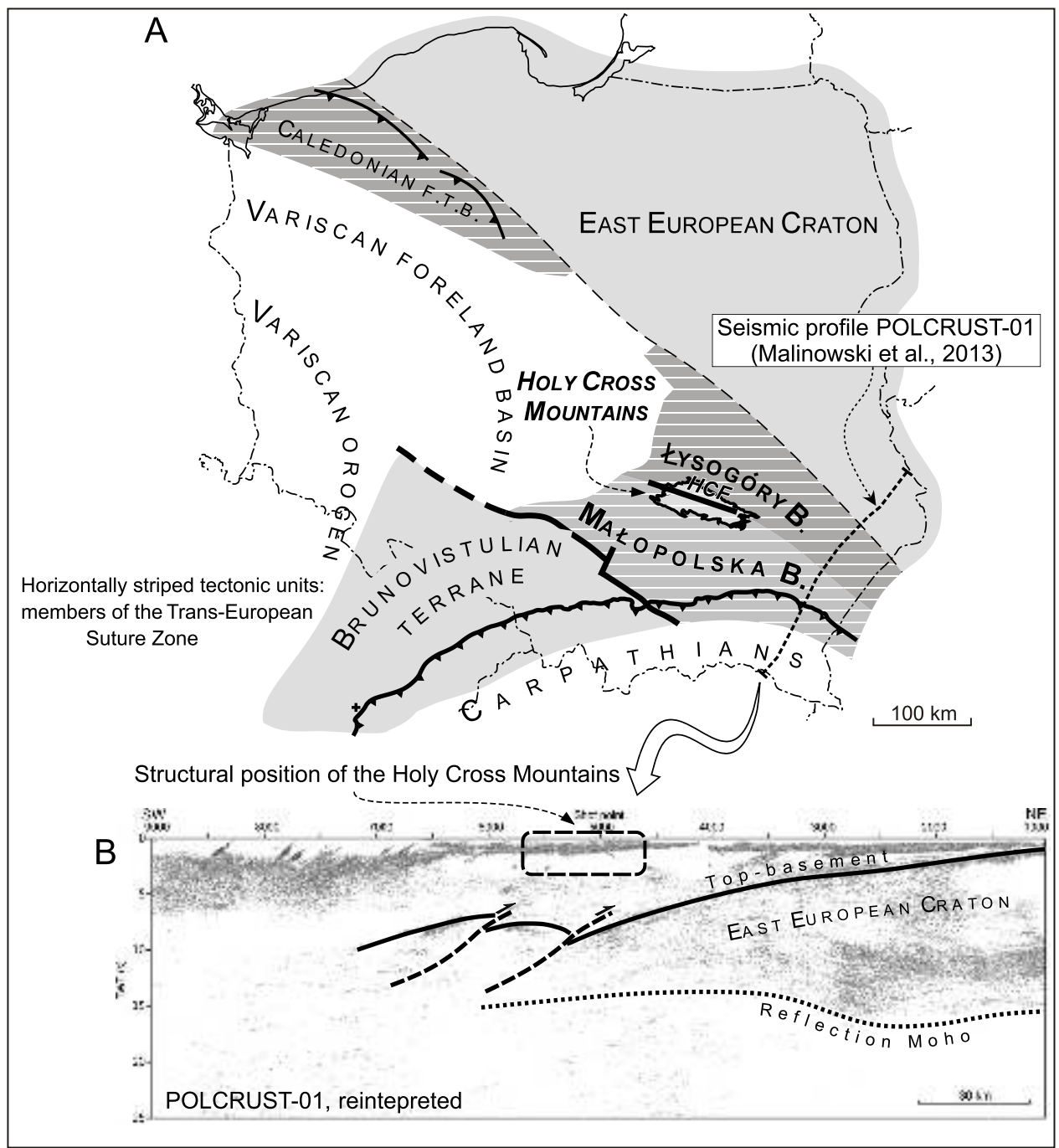

Fig. 1. Architecture of the pre-Permian basement in the Polish sector of the Trans-European Suture Zone

A - tectonic sketch; note the position of the Holy Cross Mountains astride the contact of the Łysogóry and Małopolska blocks; B - POLCRUST-01 deep reflection seismic (Malinowski et al., 2013); reinterpreted; HCF - Holy Cross Fault

Although there are several papers that provide argumentation for a Caledonian unconformity in the Łysogóry Region of the HCM or at least premises on its existence (Tokarski, 1958; Mariańczyk, 1973; Kowaczewski et al., 1976, 1989, 1998; Dadlez et al., 1994; Znosko et al., 1996; Malec, 2006), this concept is not widely accepted. Most publications stress a conformable sedimentary contact between the Late Silurian and Early Devonian sediments (e.g., Czarnocki, 1936, 1950; Mizerski, 1979; Narkiewicz et al., 2006; Kozłowski, 2008; Kozłowski et al., 2014). It affects palaeotectonic and palaeogeographic models.

In this paper, the occurrence of a Caledonian unconformity in the western part of the Łysogóry Region is further supported. Presented ideas arise from a comparison of the observed map pattern to the classical example of the Sant Llorenç de Morunys Anticline (eastern Pyrenees, Spain). Four local cross-sections are presented that constrain the geometry of this unconformity and explain why it is detectable only in the western periphery of the Łysogóry Region. A seismic analogue from the Chindwin Basin (onshore Myanmar) is presented to support the proposed model. Thin- and thick-skinned kinematic scenarios are developed and their consequences for the pre-Devonian tectonic evolution of the Łysogóry Region of the HCM are explored.

\section{OUTLINE OF GEOLOGY}

\section{PRINCIPAL STRUCTURAL CHARACTERISTICS OF THE ŁYSOGÓRY REGION}

The structural nucleus of the HCM is formed by the Paleozoic core that exposes strongly deformed pre-Permian rocks over an area of $\sim 90$ by $\sim 40 \mathrm{~km}$ in extent (Fig. 2, inset map). The Paleozoic core is surrounded from the north, west and south-west by the Mesozoic margin that comprises less deformed Permian-Mesozoic sedimentary rocks. The Paleozoic core of the HCM was exhumed during the Late Cretaceous-Paleocene inversion of the German-Polish Basin (e.g., 


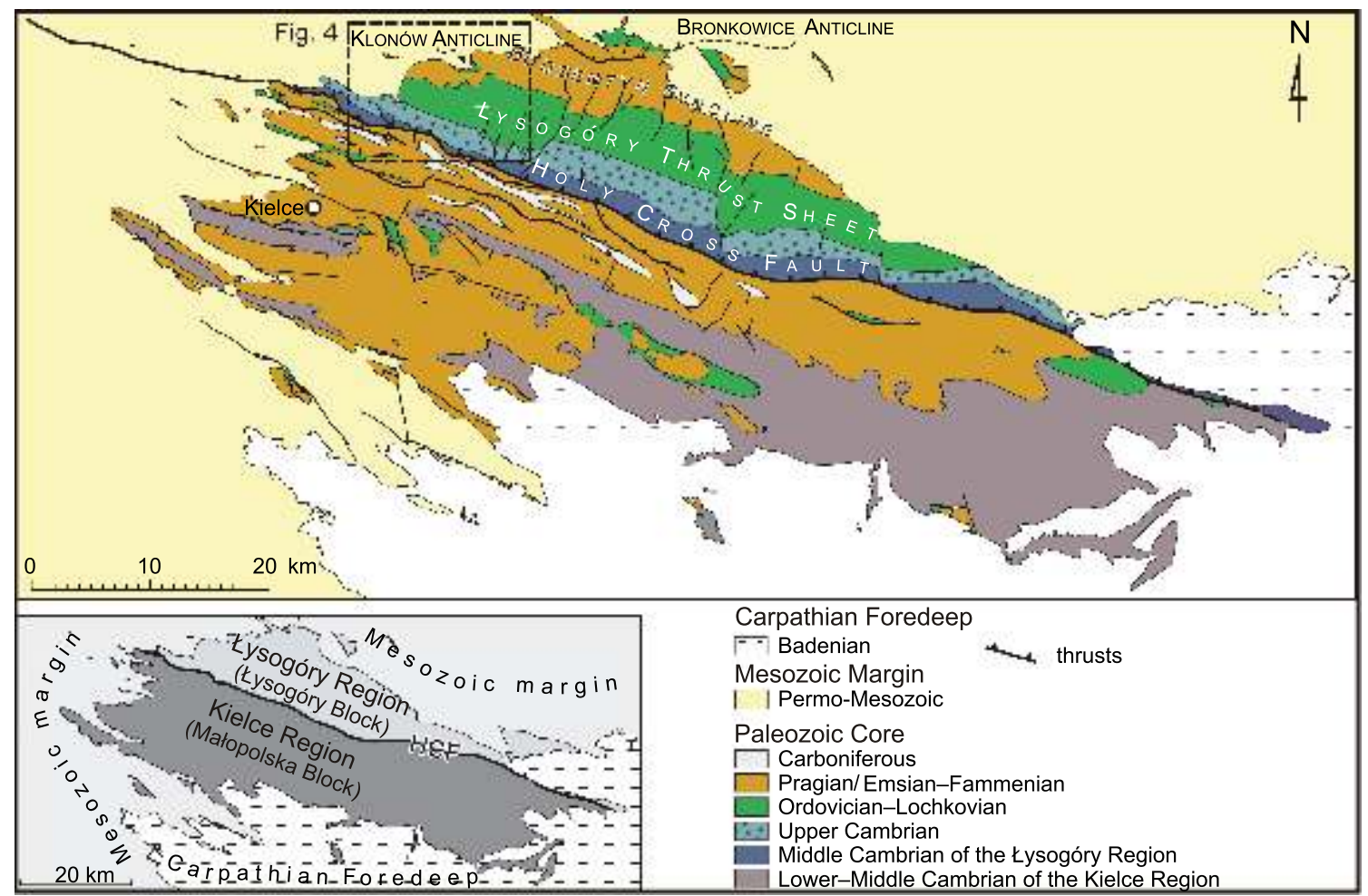

Fig. 2. Geology of the Holy Cross Mountains

Inset map: principal tectonic subdivision (HCF - Holy Cross Fault) main map - general geological map of the Paleozoic core

Kutek and Głazek, 1972; Lamarche et al., 2002, 2003). In the Miocene, the Paleozoic core and the Mesozoic margin were covered by transgressive sediments of the Carpathian foreland basin that completed the encirclement of the Paleozoic core from the south (Fig. 2).

The pre-Permian rocks of the HCM were deformed during consecutive phases of tectonic inversion: in the Late Cambrian (local Sandomirian phase, which is a time-equivalent of the Late Timanian orogeny at the northeastern margin of the EEC), Late Silurian-Early Devonian (Caledonian), ?Late Carboniferous (Variscan), and the Late Cretaceous-Paleocene.

The Łysogóry Region comprises two principal map-scale tectonic units: the Łysogóry Thrust Sheet (TS) in the south (e.g., Czarnocki, 1919, 1950; Czarnocki and Kuźniar, 1922; Stupnicka, 1988) and the Bronkowice Anticline in the north. They are separated by the Bodzentyn Syncline (Fig. 2). The Łysogóry TS, which is the main object of this study, is a tectonic slice that dips to the north-northeast at $35-60^{\circ}$ (in the west, however, up to subvertical; Mizerski, 1979). The Łysogóry TS is largely lacking map-scale fold deformation, which is expressed in a continuous succession of stratigraphic units: from the Middle Cambrian adjacent to the HCF in the south to the Famennian in the core of the Bodzentyn Syncline in the north (Fig. 2). Middle-Late Cambrian strata close to the base of the Łysogóry TS are sheared and folded (Salwa, 2006). Younger stratigraphic units, in particular Silurian, are either inferred to be folded (e.g., Czarnocki, 1950) or their homoclinal geometry is postulated (e.g., Mizerski, 1979; Kozłowski, 2008). The Łysogóry TS is compartmentalised by transverse faults (Fig. 2).
An enigmatic duo of structures called the "Klonów Anticline" and the "Barcza Syncline" occurs at the western periphery of the Łysogóry TS, close to the erosional boundary of the transgressive Permian-Triassic strata (Fig. 2). The Klonów Anticline has been portrayed in cross-sections only twice:

- Lamarche et al. (2003) have interpreted it as a slightly asymmetric, S-vergent anticline that features a constant, concentric thickness pattern of Devonian strata. Internal geometry of pre-Devonian stratigraphic units in the core of the anticline has not been illustrated.

- An earlier, more detailed cross-section by Filonowicz (1973b), although mostly based on subcrop interpretation, has indicated very low amplitude of the Klonów Anticline at the Devonian level and revealed thickness problems within Silurian strata. The latter observation is in line with the reasoning presented in this paper.

\section{STRATIGRAPHY OF THE ŁYSOGÓRY REGION}

A $\sim 7 \mathrm{~km}$ thick, near-continuous succession of Mid-Cambrian-Late Devonian sediments is exposed in the Łysogóry Region (Fig. 3). The base of the succession is defined by the HCF, which is followed along-strike for $\sim 70 \mathrm{~km}$ by the oldest exposed unit: the Middle Cambrian Góry Pieprzowe Formation (Figs. 2 and 3). The top is erosional with the youngest Famennian strata preserved only locally. The succession contains an alleged hiatus within the Pragian (Malec, 2001, 2006; Narkiewicz et al., 2006; Kozłowski, 2008; Fig. 3). 


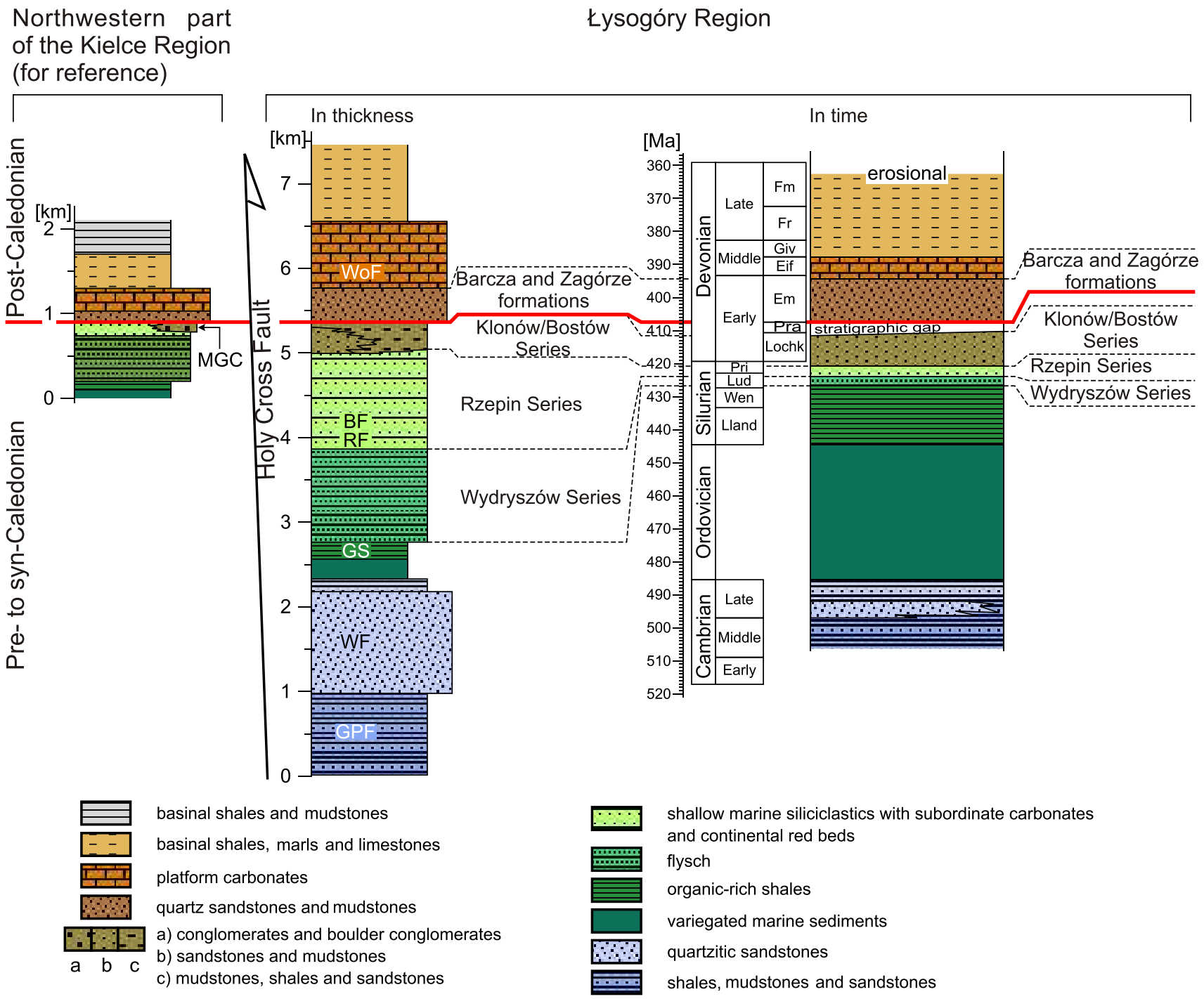

Fig. 3. Stratigraphy of the Łysogóry Region

The Upper Silurian-Lower Devonian units are based on Kozłowski (2008), Kozłowski et al. (2014) and Malec (2001, 2006); thicknesses were retrieved from geological maps, scale 1:50,000; note a disparity between the large thickness of the Wydryszów and Rzepin series and their short time of deposition; abbreviated names of additional lithostratigraphic units referred to in the text: BF - Bronkowice Fm., GPF - Góry Pieprzowe Fm., GS - graptolite shales, MGC - Miedziana Góra Conglomerate, RF - Rachtanka Fm., WF - Wiśniówka Fm., WoF Wojciechowice Fm.; time scale created using TSC Creator v. 6.3 (2015)

The stratigraphy of the Late Silurian-earliest Devonian sediments in the Łysogóry Region is insufficiently defined, as summarized e.g., by Narkiewicz et al. (2006). This is the case with the formation names and ages, as well as with vertical and lateral geometric relationships between particular stratigraphic units. The latest lithostratigraphic schemes differ from one another and are not in common use yet (Malec, 2006; Kozłowski, 2008). To avoid this confusion, the Late Silurian-earliest Devonian succession is here traditionally subdivided into the Wydryszów, Rzepin and Klonów/Bostów series from bottom to top (Czarnocki, 1950; Fig. 3). Although an oversimplification, this subdivision is consistent with the current geological maps and enables construction of serial cross-sections.

The basal part of the Late Silurian-Early Devonian succession in the Łysogóry Region is comprised of a monotonous flysch unit of the Wydryszów Series that is mid-Late Ludlowian in age. The Wydryszów Series is interpreted as a Caledonian foreland basin deposit (Kozłowski et al., 2004, 2014; Malec, 2006; Nawrocki and Poprawa, 2006; Poprawa, 2006b; Nawrocki et al., 2007; Kozłowski, 2008). The Wydryszów Series has a constant thickness, slightly in excess of $1000 \mathrm{~m}$. The overlying Rzepin Series consists of up to $\sim 1200 \mathrm{~m}$ of variegated clastic deposits of Late Ludlowian-Pridolian age. The sedimentology and fauna documented from the Rzepin Series is consistent with a shallow marine depositional environment (Czarnocki, 1919, 1950; Kozłowski, 2003, 2008). The Rzepin Series was deposited in an over-filled Caledonian foreland basin during terminal stages of its evolution (Kozłowski, 2003, 2008). The siliciclastic Klonów/Bostów Series overlies the Rzepin Series and is Late Pridolian-Lochkovian in age (Kowalczewski et al., 
1998; Malec, 2006; Kozłowski, 2008). The Klonów/Bostów Series is around $300 \mathrm{~m}$ thick and includes marine and continental units (Kowalczewski et al., 1998; Kozłowski, 2008).

The Late Silurian-earliest Devonian stratigraphic section of the Łysogóry Region is capped by a short-term hiatus that comprises the Early and Middle Pragian (Czarnocki, 1936; Malec, 2001, 2006; Narkiewicz et al., 2006; Kozłowski, 2008). The gap is succeeded by ?Late Pragian-Emsian siliciclastics that belong to the Barcza and Zagórze formations (Fig. 3). The basal Barcza Fm. is a transgressive unit that features an estuarine facies association. These two formations attain a combined thickness of $\sim 650-900 \mathrm{~m}$.

In contrast to the Łysogóry Region, the Upper Silurian-lowest Devonian section in the Kielce Region is thin and less complete and it is often missing over large areas. Transgressive Emsian sediments in the Kielce Region, which are correlatable with the Barcza Fm. of the Łysogóry Region, commonly rest on top of Lower Cambrian units. However, in the northwestern part of the Kielce Region, which is adjacent to the segment of the Łysogóry Region analysed in this paper, the difference is less distinctive. Here, the Late Silurian-earliest Devonian succession resembles that of the Łysogóry Region in terms of facies, albeit thinner and less complete (Czarnocki, 1919, 1936, 1950; Malec, 2001, 2006; Fig. 3). The conspicuous Miedziana Góra Conglomerate has been identified in the uppermost part of the Upper Silurian section of the northwestern Kielce Region (Czarnocki, 1919). According to the original record, later corroborated by Malec $(2001,2006)$, the conglomerate consists of boulder-size blocks of Upper Cambrian quartzites identical to those of the Wiśniówka Fm. in the Łysogóry Region (Fig. 3). The addition of pebbles derived from the Cambrian and Ordovician of the Kielce Region is, however, used as evidence against a Łysogóry Region provenance for the Miedziana Góra Conglomerate (Kozłowski, 2008; Kozłowski et al., 2014). This stratigraphic unit plays an important role in geometric and kinematic restorations presented below.

\section{DATA AND METHODS}

\section{CARTOGRAPHIC EVIDENCE}

The western part of the Łysogóry Region was mapped in the scale 1:50,000 by the Polish Geological Institute (Filonowicz, 1970, 1973b; Fig. 4). The maps include the Quaternary cover (Fig. 4A) but are associated with subcrop sketches that interpolate the covered stratigraphic contacts between the available wells (Fig. 4B). The subcrop sketches are to some extent influenced by the tectonic concepts of their authors. Nevertheless, they were used as an input to the cartographic analysis in order to assure that the conclusions are built on commonly available materials and are therefore verifiable. The key area of the Klonów Anticline has been accurately mapped by Kowalczewski et al. (1989) (Fig. 4). This map relies on surface data and shallow geoelectric sounding that allowed for tracing $\mathrm{Pa}-$ leozoic lithological complexes under the Quaternary cover.

The maps by Filonowicz (1970, 1973b) and by Kowalczewski et al. (1989) are not always mutually consistent which becomes evident after accurate georeferencing. The outcrop information included in the maps by Filonowicz $(1970,1973 b)$ has been used as the decisive criterion in case of ambiguity. When the outcrop information was missing, the priority has been given to the more recent map by Kowalczewski et al. (1989).

\section{CROSS-SECTION CONSTRUCTION AND UNFOLDING}

The subsurface structural model has been constructed using the kink (bisector) method (e.g., Suppe, 1983). This basic technique of cross-section construction permits in-depth extrapolation of exposed stratigraphic contacts in accordance with dip data. The resultant geometries consist of dip domains containing beds with a constant dip angle separated by axial planes of successive kinks. Reliability of this method depends on the structural context: it gives best results for detachment folds but it is of a limited use, e.g. for rollover anticlines. Thin-skinned thrust sheets may be reconstructed reliably; however, the higher inclination of a thrust sheet the shallower is an angle at which the dip information is projected. This simple geometric limitation influences the depth of credible extrapolation of surface data. Therefore, the subsurface structural interpretation of the Łysogóry TS is not only tied to the data directly projected onto the cross-section plane, but it also honours along-strike geometric relationships. A representative cross-section was unfolded to the base-Barcza Fm. using a flexural slip algorithm. This restoration method preserves lengths of lines (stratigraphic boundaries) provided they are parallel to the marker horizon. The cross-section area and thicknesses of beds are preserved as well. Pin lines for the restoration were placed in the area of a presumed minimum layer-parallel slip. Midland Valley Move ${ }^{\circledR}$ package was used for the data integration, cross-section construction and unfolding.

\section{OBSERVATIONS}

\section{MAP PATTERN IN THE VICINITY OF THE KLONÓW ANTICLINE}

In the area of the Klonów Anticline, the outcrop extent of the Barcza and Zagórze formations broadens to the south, as opposed to the regular homoclinal belt that they form further to the east (Fig. 4B). In contrast, the outcrop extent of the underlying Klonów/Bostów Series and particularly the Rzepin Series decreases to the west (Fig. 4B). The exposure width of the Klonów/Bostów Series drops from $\sim 1170 \mathrm{~m}$ in the east to $\sim 515 \mathrm{~m}$ in the west. The width of the Rzepin Series reaches $\sim 2150 \mathrm{~m}$ in the east and drops to $\sim 500 \mathrm{~m}$ in the west. The base of the Rzepin Series is also offset to the south and results in a reduction of the outcrop extent of the underlying Wydryszów Series from $\sim 1600 \mathrm{~m}$ in the east to $\sim 520 \mathrm{~m}$ in the west (Fig. 4B).

These offsets of stratigraphic boundaries create a peculiar map pattern of the Klonów Anticline and the Barcza Syncline. The Klonów Anticline has limbs of the Barcza and Zagórze formations, which encircle the core of the Klonów/Bostów Series (Fig. 4B). The Barcza Syncline is outlined by a mildly folded lobe of the Barcza and Zagórze formations. It has an irregular outline which is topography-controlled to a significant extent. It emphasizes an open, flat-bottom geometry of the Barcza Syncline. The Barcza and Zagórze formations merge towards the east into a single homoclinal belt parallel to the underlying and overlying stratigraphic units. The eastern extension of the Klonów Anticline and the Barcza Syncline is covered by transgressive Permian-Triassic strata with a single inlier of Paleozoic rocks that exposes the Eifelian Wojciechowice Fm. (Fig. 4B).

The dip pattern of the Upper Silurian-Lower Devonian strata around the Klonów Anticline indicates some geometric compli- 

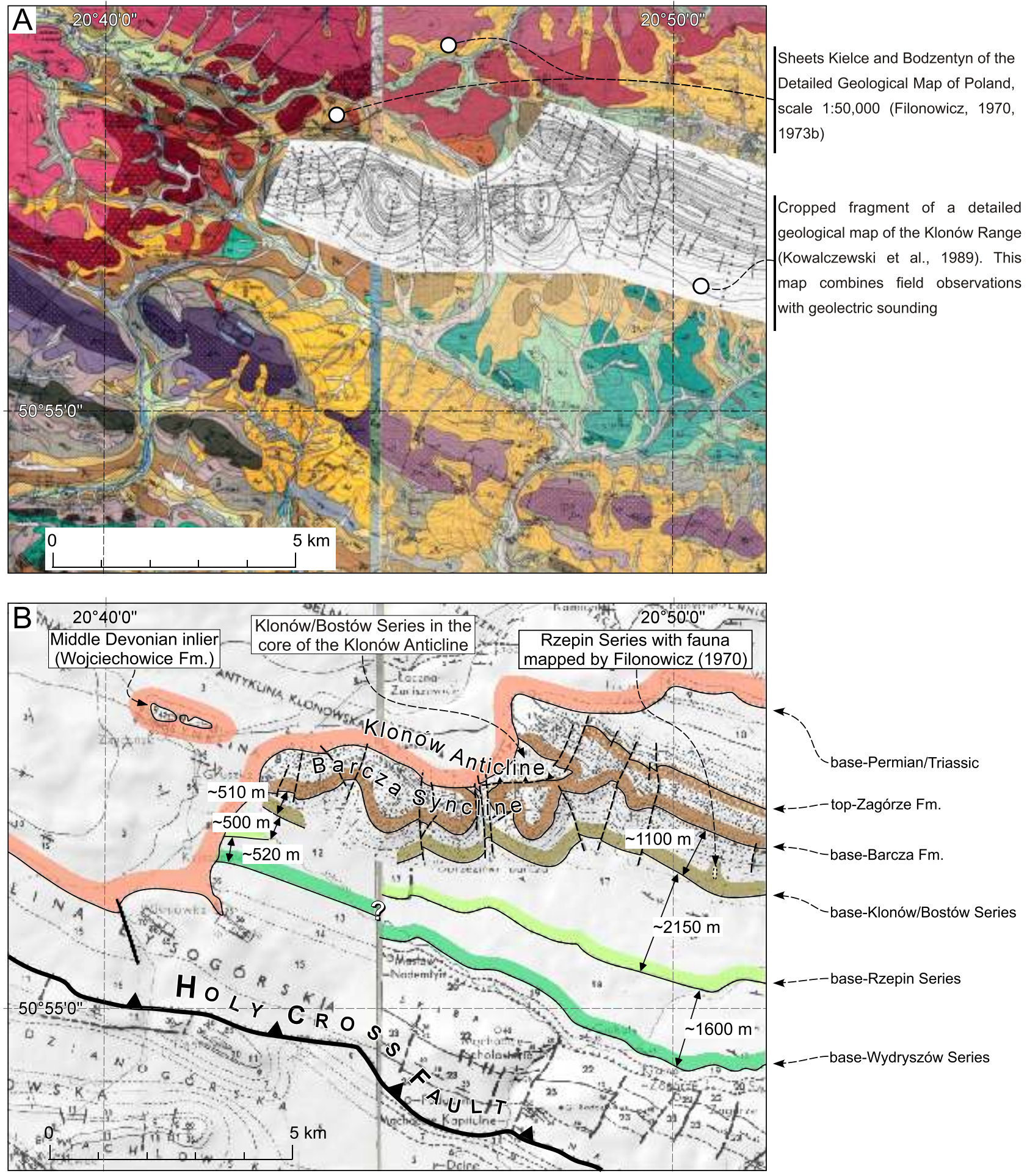

2. A mismatch between the adjacent sheets Kielce and Bodzentyn of the Detailed Geological Map of Poland in the scale 1:50,000 (Filonowicz, 1970, 1973b)

Fig. 4. Geological mapping data on the western part of the Łysogóry Region

A - a mosaic of geological maps showing the Quaternary cover (Filonowicz, 1970, 1973b; Kowalczewski et al., 1989); B - a mosaic of "uncovered" geological maps with subcrop interpretation (Filonowicz, 1969, 1973a; Kowalczewski et al., 1989); key stratigraphic markers are highlighted 
cations. To the east of the Anticline the entire Paleozoic section is roughly homoclinal. The dip measurements plotted in the geological map by Filonowicz (1973b) cluster between 30 and $40^{\circ}$. This, however, does not comply with the exposure width of the Klonów/Bostów Series that may exceed 1100 m (map by Kowalczewski et al., 1989) despite the unit's thickness of only $\sim 300 \mathrm{~m}$ (Kozłowski, 2008). A simple geometric calculation would imply the mean dip angle of $\sim 16^{\circ}$ instead of the regional $30-40^{\circ}$. It suggests that the Klonów/Bostów Series may be not coplanar with the underlying sequence. The occurrence of the Rzepin Series with fauna, mapped by Filonowicz (1970) in the area occupied by the Klonów/Bostów Series (Kowalczewski et al., 1989), is in line with this simple observation (Fig. 4B). This inlier may represent an erosional window through which the moderately dipping Rzepin Series emerges from beneath the flat-lying Klonów/Bostów Series. In the area of the Klonów Anticline, the simple dip pattern is preserved only within the Cambrian-Upper Silurian part of the section, although the Cambrian is dipping steeper, up to subvertical. Nevertheless, the structure of the pre-Devonian section is considered generally coplanar as the bedding strike remains constant. The situation changes upper in the section. The Klonów/Bostów Series together with the overlying Barcza and Zagórze formations define the Barcza Syncline and the Klonów Anticline, which are superposed onto the homoclinal Rzepin Series dipping to the north-northeast. Hence, the structure is three-dimensionally non coplanar.

\section{GEOMETRIC INTERPRETATION \\ PREFERRED SOLUTION: PROGRESSIVE UNCONFORMITY}

This model results from comparison of the observed map pattern to that of the Sant Llorenç de Morunys Anticline in the eastern Pyrenees (Spain). This well-studied anticline hosts classical examples of growth strata deposited in a foreland setting (e.g., Suppe et al., 1997; Ford et al., 1997; William et al., 1998; Fig. 5). A detailed anatomy of the folded package results from migration of the synclinal axis through undeformed beds

\section{Sant Llorenç de Morunys Anticline}

Map from Ford et al. (1997), cross-section from Suppe et al. (1997)

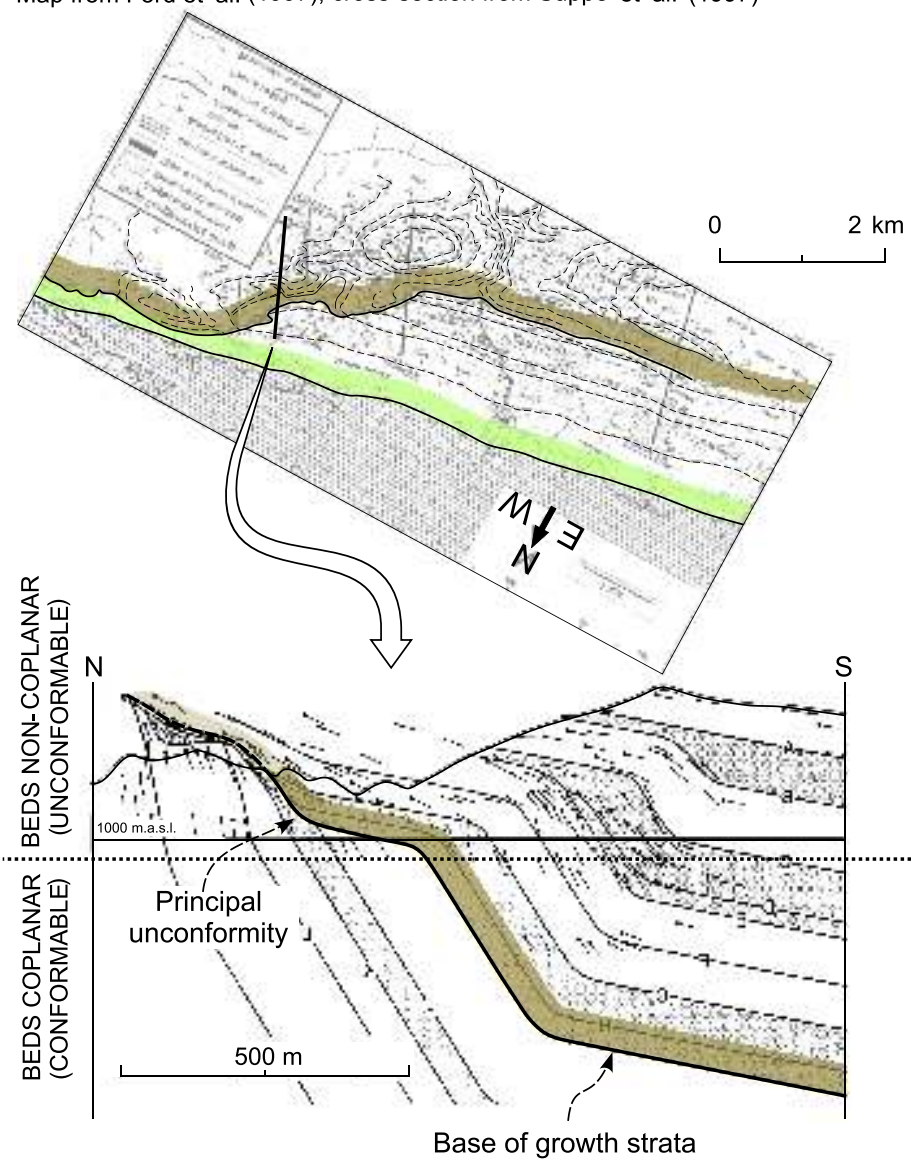

Western part of the Łysogóry Thrust Sheet
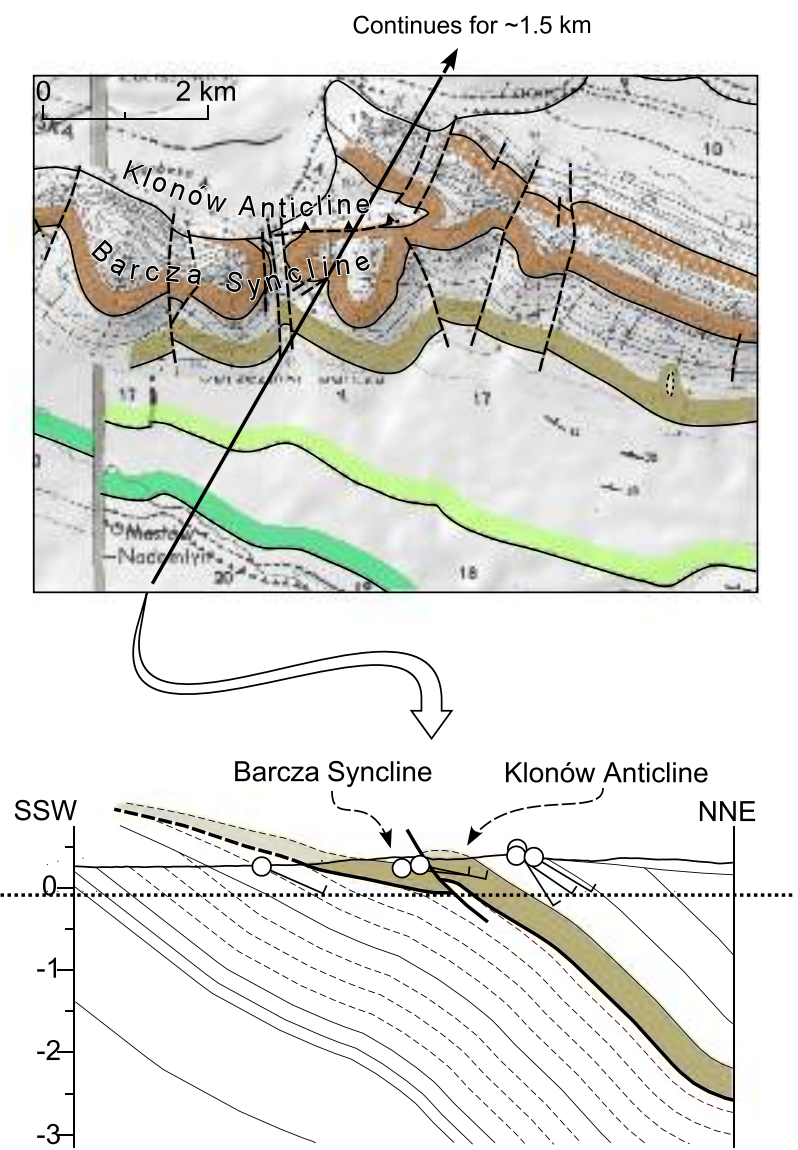

Fig. 5. Northern flank of the Sant Llorenç de Morunys Anticline (Ford et al., 1997; Suppe et al., 1997) as the analogue to the western part of the Kysogóry Thrust Sheet

The map image of the Sant Llorenç de Morunys Anticline results from an intersection of a progressive unconformity at successively shallower structural levels from east to west; given the similarity of the surface patterns, the same solution may be readily applied to the subsurface of the Klonów Anticline; the map of the Sant Llorenç de Morunys Anticline flipped and rotated colours assigned arbitrarily to facilitate comparison 
coeval with a syn-kinematic erosion and/or deposition, depending on the local sedimentation/uplift rates. The syn-kinematic strata that were deposited in the foreland position with respect to the migrating synclinal axis remain coplanar with the underlying pre-kinematic strata. On the contrary, those deposited directly behind the migrating kink display growth geometries that pass to an angular unconformity on top of the previously tilted beds. This special case of unconformity is termed "progressive" as it passes down-dip and basinwards into a continuous stratigraphic sequence (e.g., Riba, 1976; Rafini and Mercier, 2002). In consequence, it is the level at which the structure is observed, deciding whether the section appears conformable or it is split by an angular unconformity (Fig. 5).

These subsurface geometric relationships give rise to a diagnostic map image (Fig. 5). Depending on the level of erosion, the map pattern may be either homoclinal or the older homo- clinal units may be mantled by the younger transgressive strata. Both cases are observed in the geological maps of the Sant Llorenç de Morunys Anticline and the western part of the Łysogóry TS (Fig. 5). Although in details this analogy is not perfect, in particular no growth strata in the Late Silurian/Early Devonian sequence of the Łysogóry TS have been identified so far and the deformation history is different, but the concept of a progressive unconformity is applicable to both cases. Therefore, the subsurface structure of the Sant Llorenç de Morunys Anticline is used as the interpretational clue that helps to interpret the Klonów Anticline as a gently folded progressive unconformity preserved due to less erosion in the western part of the Łysogóry TS than in the centre of this unit.

This inferred progressive unconformity in the western periphery of the Łysogóry TS is composite. It consists of three individual discordance surfaces of: at the base of the Rzepin Series, at the

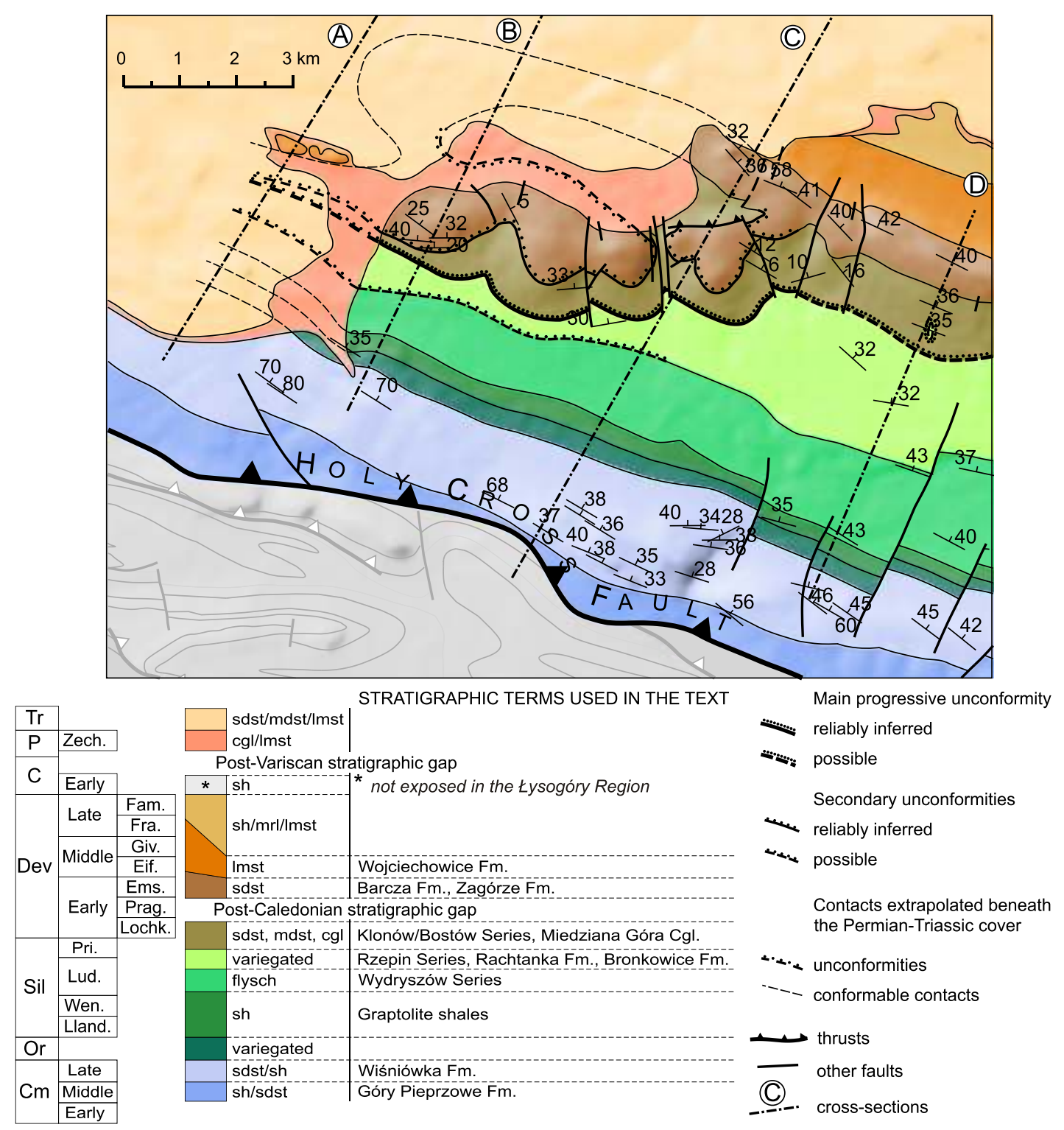

Fig. 6. Klonów Anticline as a folded, progressive Caledonian unconformity: geological map

The map is based on Filonowicz (1970, 1973b) and Kowalczewski et al. (1989); Kielce Region has been faded in order to emphasize the structural pattern of the Łysogóry Region; lithological abbreviations: cgl - conglomerate, Imst - limestone, mdst - mudstone, mrl - marl, sdst - sandstone, sh - shale 

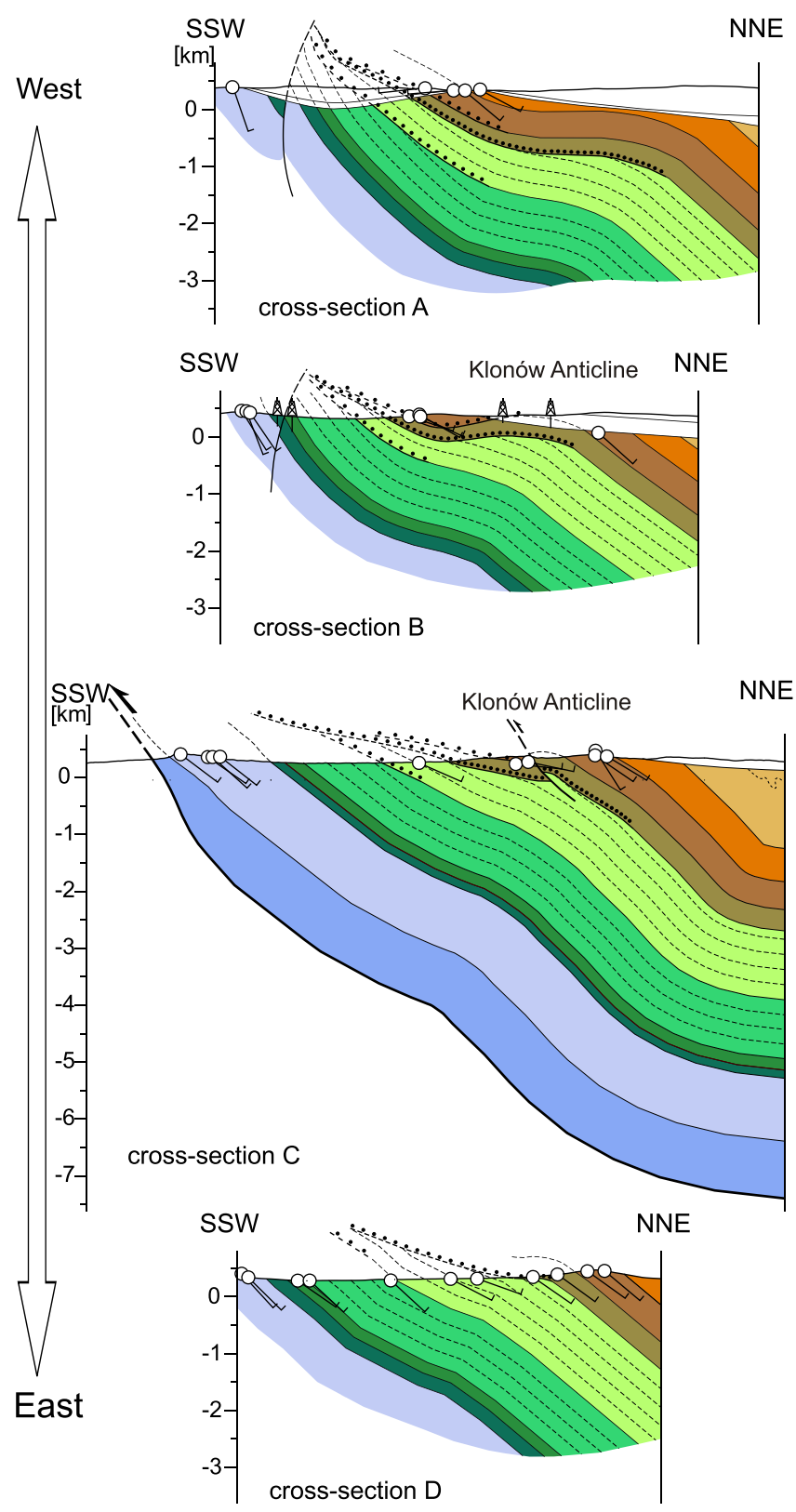

Fig. 7. Klonów Anticline as a folded, progressive Caledonian unconformity: serial cross-sections

Cross-section $\mathrm{C}$ is more complete than the others because it is used for restoration and to discuss kinematic scenarios; colour code as in Figure 6

base of the Klonów/Bostów Series, and at the base of the Barcza $\mathrm{Fm}$. The principal progressive unconformity is the one at the base of the Klonów/Bostów Series, the two others are minor. This is illustrated with an updated geological map and four serial cross-sections (Figs. 6 and 7). The map retains all of the field and borehole evidence included in the original maps (Filonowicz, 1970, 1973b; Kowalczewski et al., 1989; Fig. 4). The new map and the cross-sections form a geometrically consistent "2.5D" framework that permits along-strike tracing of geometries.

The lowermost of the three unconformities is inferred to occur at the base of the Rzepin Series. As evident from the position of stratigraphic contacts, this unconformity incises $\sim 150 \mathrm{~m}$ into the underlying Wydryszów Series in the area of cross-section B. Further to the east it diminishes but it is still discernible in the area of cross-section C. Along cross-section D, the contact between the Wydryszów Series and the Rzepin Series is conformable (Fig. 7). According to Kozłowski (2008), the Rzepin Series in this area begins with continental red beds of the Rachtanka Fm., which pass upward into marginal marine deposits of the Bronkowice Fm. This evidence for a transgressional succession overlying incised continental units supports the concept of an unconformity at the base of the Rzepin Series.

The main unconformity underlies the Klonów/Bostów Series. This cuts up to $\sim 900 \mathrm{~m}$ into the underlying Rzepin Beds and is responsible for most of the cartographic complications described previously. The angular discordance at the base of the Klonów/Bostów Series reaches $\sim 15^{\circ}$ along the best-constrained cross-section $\mathrm{C}$. The angle may be higher (possibly up to $30^{\circ}$ ) for the neighbouring cross-sections B. However, this estimate requires further confirmation. The unconformity at the base of the Klonów/Bostów Series is exposed at increasingly deeper levels to the east. As a result, a successively more complete sequence crops out in this direction. Only the deepest remnant of this discordance is still inferred in cross-section D, while further east, the unconformity remains entirely above the present erosion level.

The contact between the Klonów/Bostów Series and the overlying Barcza Fm. is largely concordant. However, there is a possibility for a slight S-ward thinning of the former. In crosssection $B$, the lowest thickness of the Klonów/Bostów Series constrained by the cartographic image and dip data is $\sim 180 \mathrm{~m}$, while in cross-section $D$, the lowest thickness that assures consistency with the surface data is $\sim 370 \mathrm{~m}$. It can be either due to a low-angle unconformity at the base of the Barcza Fm. (Kowalczewski et al., 1989, 1998) or due to a depositional thinning of the Klonów/Bostów Series.

\section{ALTERNATIVE SOLUTION: STAIRCASE THRUST}

This scenario takes into account an uncertainty concerning the internal structure of the Silurian series. It was already Czarnocki (1950) who noted that the thickness of the Silurian profile might be tectonically multiplied. More recent works stress a homoclinal structure of this series (e.g., Kozłowski, 2008). Although the map image seems to support the latter view, poor outcrop conditions impede a univocal validation of either of these two possibilities.

The alternative model (visualised as a rebuilt version of cross-section C) explains the observed map pattern (Fig. 8A) by a staircase thrust (Fig. 8B). The basal detachment is placed in the Lower Silurian graptolite shales. This guess is reasonable concerning the mechanical stratigraphy and the regional context: the graptolite shales act as a detachment in the northern part of the Kielce Region (Gagała, 2014). In order to explain the geometric pattern along cross-section $\mathrm{C}$, an intermediate detachment must be assumed near the contact of the Rzepin and Klonów/Bostów series. This is also not unlikely given rather incompetent lithologies of the Rzepin Series. The basal and intermediate detachments are connected by a ramp that cuts through the Wydryszów and Rzepin series. With this simple thrust geometry, the dip-slip displacement is $\sim 1800 \mathrm{~m}$.

Concerning the 2D geometry along cross-section $\mathrm{C}$, this model shows a reasonably good fit to the local surface data and offers an uncontroversial subsurface solution (Fig. 8B). In comparison to the "unconformity" solution, this model implies a thinner Upper Silurian-lowest Devonian section: 2500 m vs 

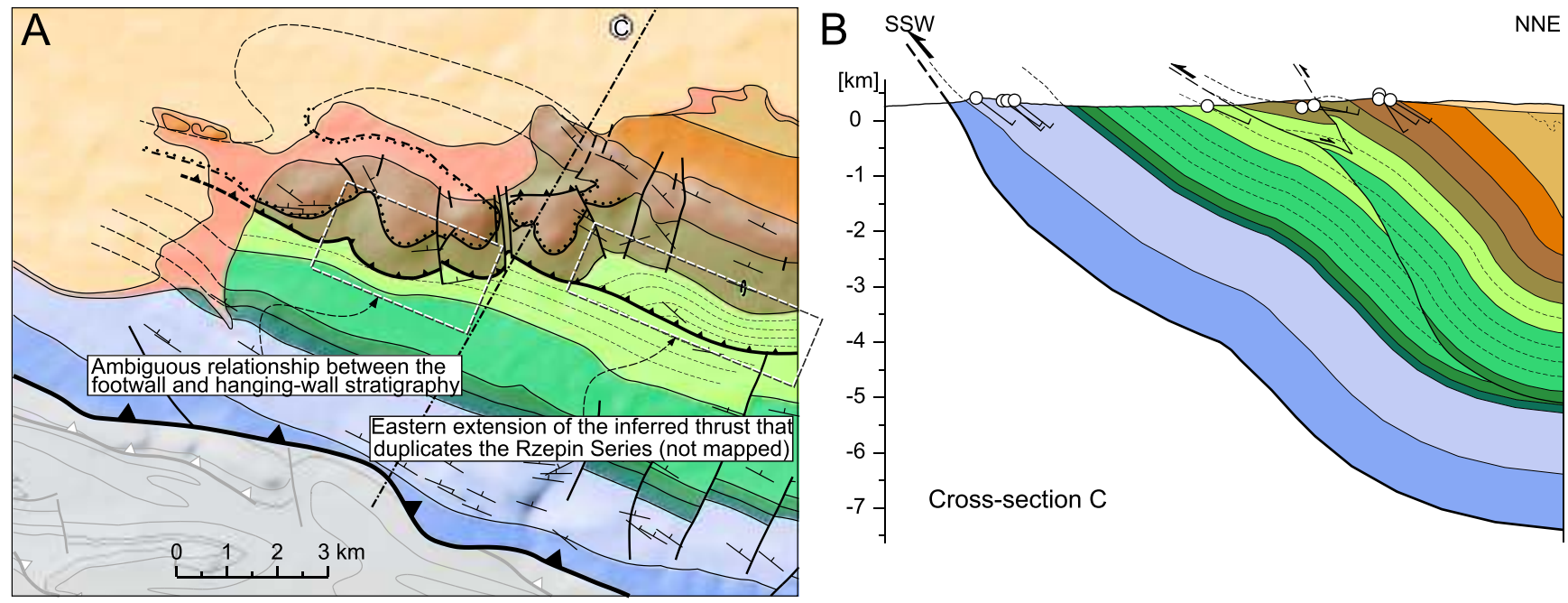

Fig. 8. Klonów Anticline as a hanging-wall anticline of a thrust sheet displaced along a staircase thrust: $A$ - alternative map-view and B - subsurface interpretations

The map is based on Filonowicz (1970, 1973b) and Kowalczewski et al. (1989); colour code as in Figure 6

$\sim 1950 \mathrm{~m}$. Both these figures fall within the acceptable range (Kozłowski, 2008). However, this model creates problems if analysed in 3D.

The eastern extension of the inferred thrust would have to result in a stratigraphic repetition of the Rzepin Series (Fig. 8A). Neither such a repetition nor the thrust itself have been mapped so far, although poor outcrops do not rule it out definitively. To the west, the inferred thrust must be placed progressively deeper in the footwall stratigraphy, to comply with the narrowing belt of the Rzepin Series, which may result from a lateral ramp that displaces the intermediate detachment deeper into the footwall. However, such a geometry of the basal thrustwould have to find its expression in a more complete hanging-wall stratigraphy, which is not the case. Another possibility is an out-of-sequence thrust cutting down-section. Although possible from the geometric point of view, an out-of-sequence thrust is not likely in a non-orogenic setting that has experienced only limited shortening.

Although this alternative solution cannot be completely ruled out, the inherent 3D problems make it inferior to the progressive unconformity hypothesis. Therefore it will not be further developed.

\section{CROSS-SECTION RESTORATION}

\section{RESTORED EARLY DEVONIAN GEOMETRY}

The well-constrained geometry of the progressive unconformity permits the restoration of the latest Silurian-earliest Devonian deformation pattern in the western part of the Łysogóry TS. Cross-section $\mathrm{C}$ has been unfolded to the base of the Barcza Fm. (Fig. 9). Cambrian-Silurian strata in the restored cross-section dip by $\sim 20^{\circ}$ to the north. The beds turn to horizontal down-dip across a well-defined kink plane. The base of the Barcza Fm. can be used as an unfolding template only in the northern part
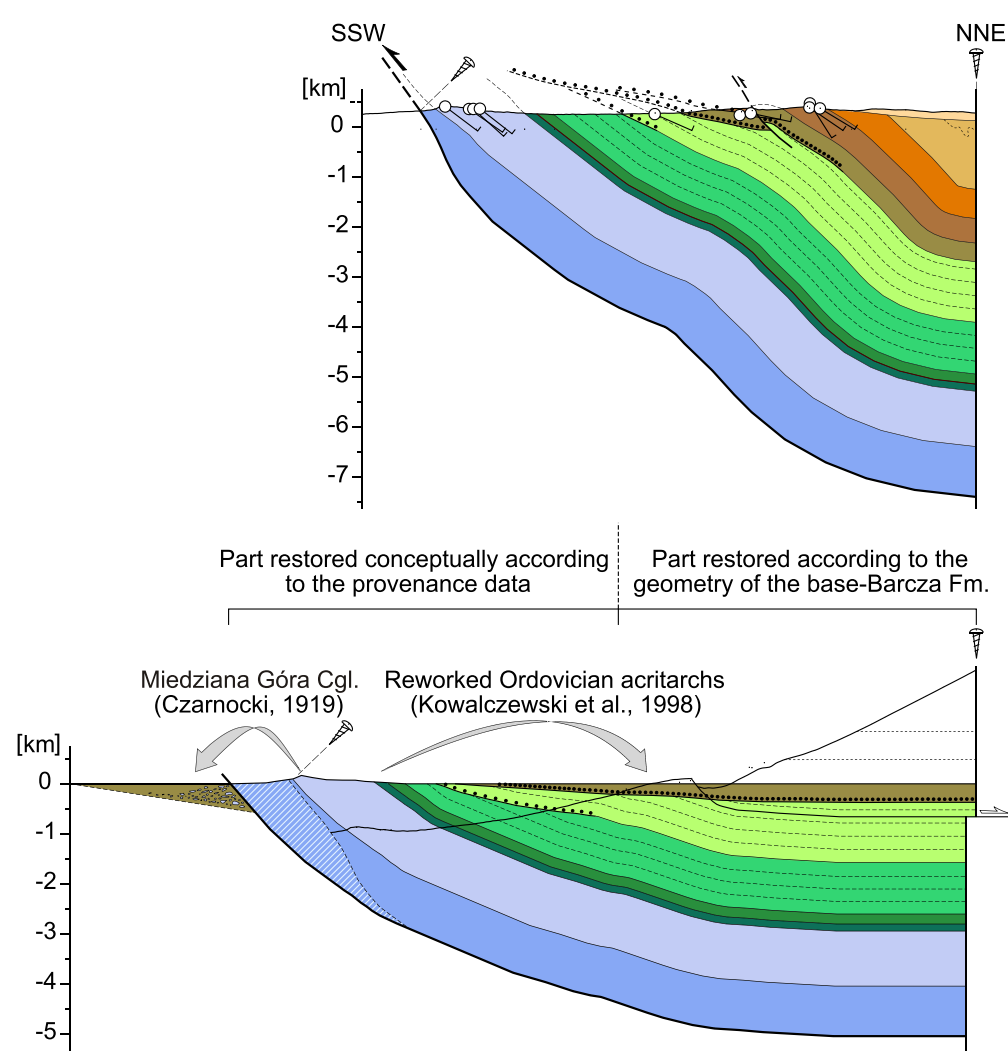

Fig. 9. Restored Early Devonian geometry along cross-section C

Colour code and symbols as in Figure 6

of the restored cross-section. In the southern part, it remains above the present erosion level. Here, a continuation of the tilted flank is indicated by the Miedziana Góra Conglomerate in the footwall of the HCF (Fig. 9). These strata contain boulders of quartzite sandstones coming from the Upper Cambrian 
Wiśniówka Fm. Hence, the Miedziana Góra Conglomerate is a record of the exhumation of almost the entire sedimentary succession of the Łysogóry TS during the latest Silurian-earliest Devonian shortening. Moreover, Kowalczewski et al. (1998) provided evidence on reworked Ordovician acritarchs in the Klonów/Bostów Series, which further supports an exhumation and erosion of the leading edge of the Łysogóry TS. The southern part of cross-section $\mathrm{C}$ has been restored accordingly, although the geometry (particularly the dip angles) is diagrammatic.

\section{SEISMIC ANALOGUE}

In order to support the proposed interpretation, a seismic analogue from the Chindwin Basin, onshore Myanmar, is presented (Fig. 10; a line drawing of an unpublished seismic line from author's collection of seismic examples compiled from various public domain sources). The seismic line reveals a thin-skinned thrust sheet that carries a folded angular unconformity with an angular discordance of between $5^{\circ}$ to $12^{\circ}$. The same unconformity can be traced in the footwall. The stratigraphy below the unconformity becomes increasingly more complete down-dip. On the extreme right of the seismic line, the unconformity becomes sub-parallel to the reflectors. These features are indicative of a progressive unconformity, analogous to that from the Łysogóry TS. The unconformity in the seismic line from the Chindwin Basin was generated by the general tilt of the sedimentary succession and the basement. Subsequent shortening led to the rotation of the unconformity in the hanging wall of a thin-skinned thrust. The Chindwin Basin experienced much less erosion than the Łysogóry Region of the HCM. However, if the erosion level is arbitrarily placed at a level comparable to that in the Łysogóry TS, the resultant "dip" and "stratigraphic" patterns are reasonably similar (Fig. 10).

\section{DISCUSSION}

\section{LATERAL EXTENT OF THE PROGRESSIVE UNCONFORMITY}

The progressive Caledonian unconformity is observed at increasingly deeper structural levels from west to east. It permits a reliable reconstruction of the subsurface geometry (crosssections B-D in Fig. 7). To the east of the Klonów Anticline, the unconformity remains above the present erosion level and therefore it is not traceable over most of the Łysogóry TS (Fig. 11). It may be due to the general westward tilt of the Paleozoic core or due to the increase in the amount of Variscan slip along the HCF.

The contact between the Klonów/Bostów and Rzepin series remains conformable up to the eastern limit of the reliably mapped part of the Łysogóry TS. Further east, the evidence consists of a few scattered outcrops and wells. The conform-

\section{A Seismic analogue (Chindwin Basin onshore Myanmar)}

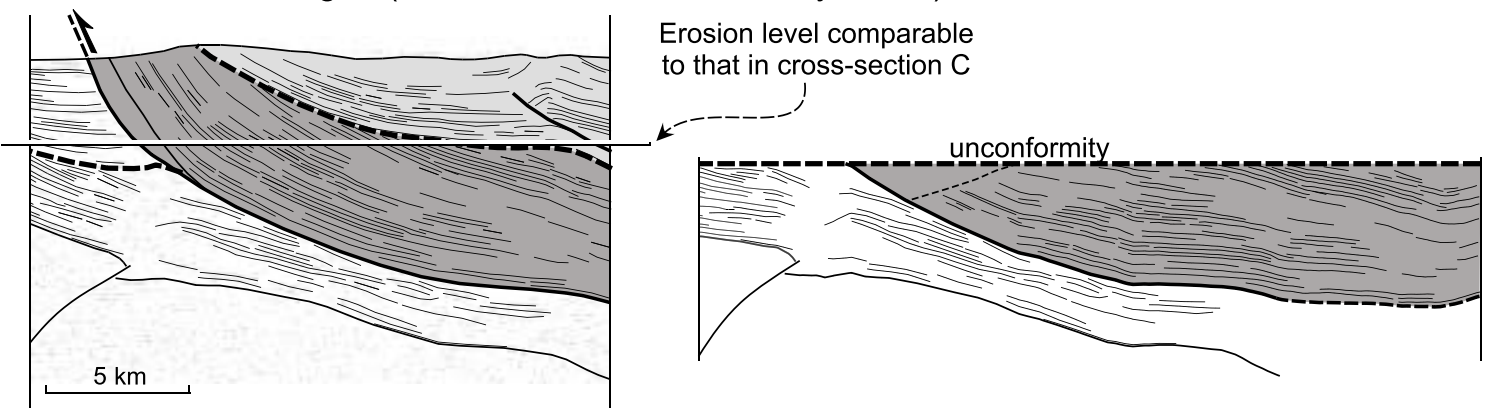

\section{B Łysogóry Thrust Sheet (cross-section C)}
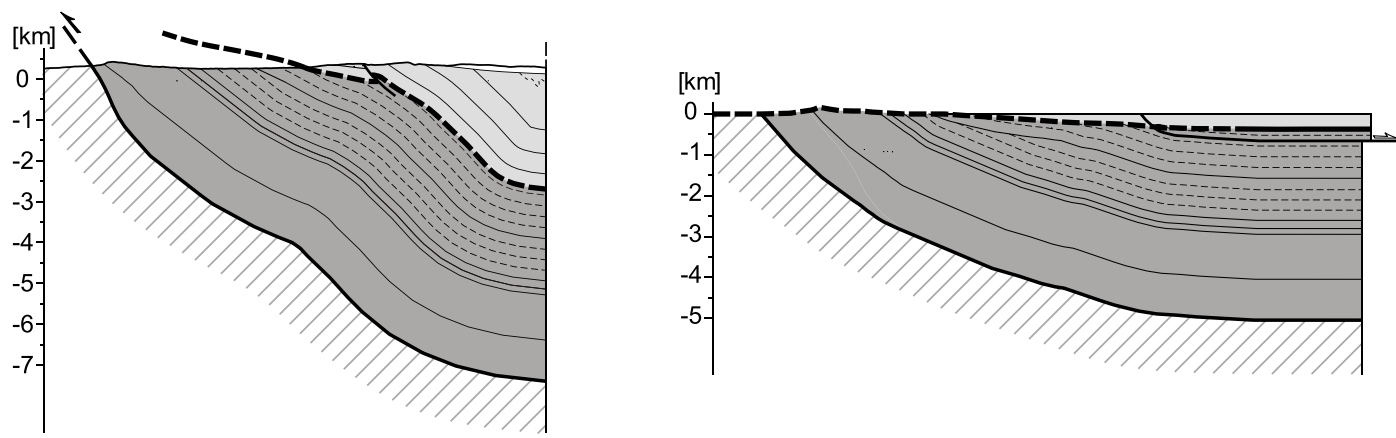

post-kinematic (post-Caledonian) strata

(Caledonian) unconformity

pre-kinematic (pre-Caledonian) strata

Fig. 10. Seismic analogue (line drawing) from the Chindwin Basin, onshore Myanmar, which shows a progressive unconformity deformed by subsequent thrusting

A - interpreted seismic section, original and restored to the unconformity; B - cross-section C, original and restored to the base-Barcza Fm. 


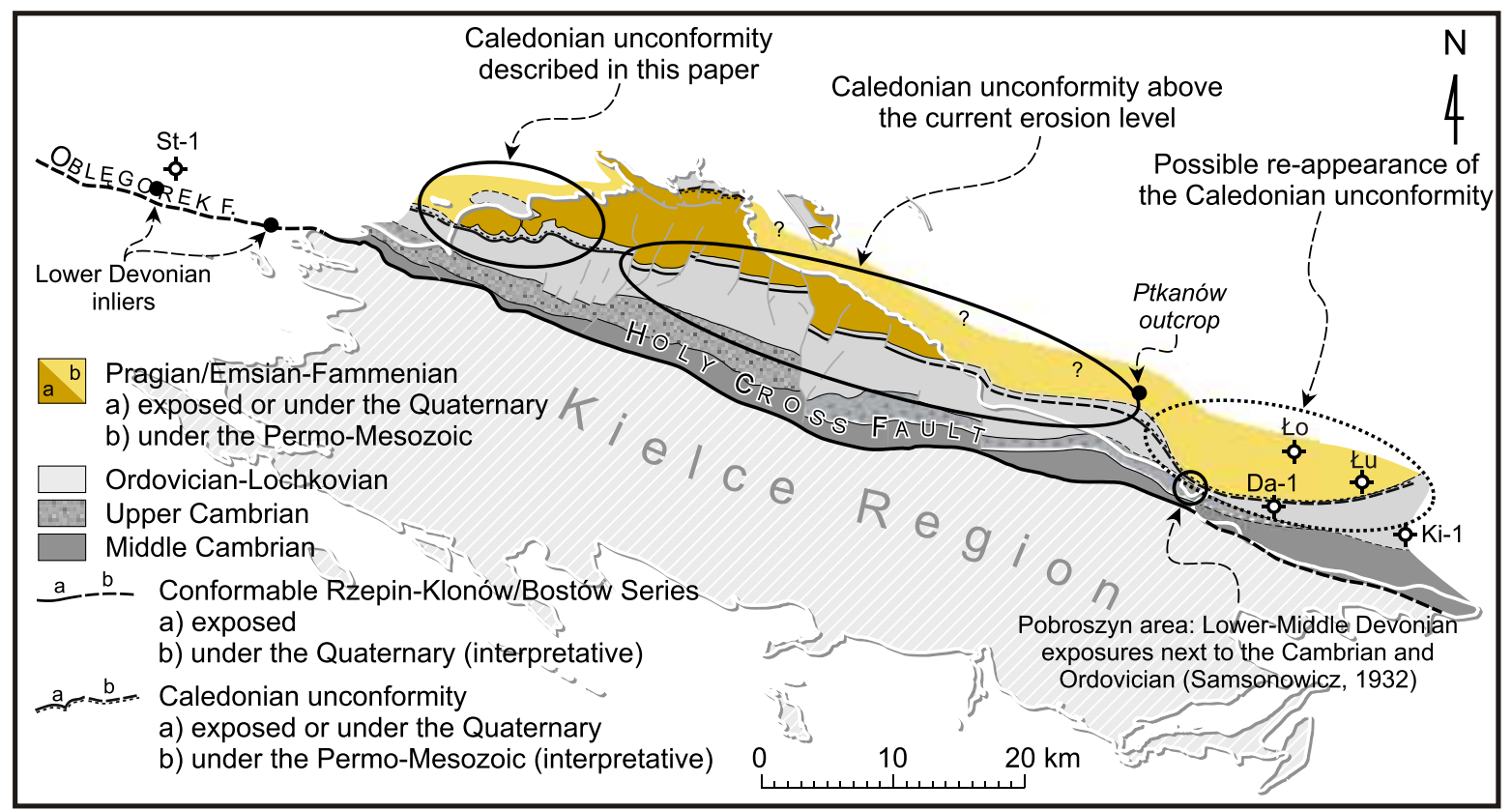

Fig. 11. The along-strike extent of the progressive Caledonian unconformity (interpretative)

The unconformity is exposed in the western part of the Łysogóry Thrust Sheet; over the central part, it remains above the present erosion level; narrowing of the Silurian belt indicates that the unconformity may return below the present erosion level in the east; to the west of the Paleozoic core, the evidence is ambiguous; boreholes: Da-1 - Daromin IG 1, Ki-1 - Kichary IG 1, Ło - Łopata, Łu - Łukawa, St-1 - Stachura-1; structure and stratigraphy of the Kielce Region are not illustrated for the sake of clarity

able Silurian-Devonian sequence seems to extend further east up to the isolated exposure of the Barcza Fm. in Ptkanów (Fig. 11). However, in the area of Pobroszyn situated only $\sim 8 \mathrm{~km}$ from Ptkanów, the Lower and Middle Devonian strata are proximal to the trace of the HCF and the Silurian belt is almost absent (Samsonowicz, 1932; Fig. 11). This pattern is a mirror reflection of that from the area of the Klonów Anticline, and may result from a re-appearance of the Caledonian unconformity in that area due to the shallower structural level exposed at the present erosional surface. This is consistent with one of the cross-sections published by Kowalczewski et al. (1976), which shows a conspicuous base-Devonian discordance in this area. Further east, the trace of the inferred unconformity shall be interpolated between the Łopata and Łukawa boreholes on one side, and the Daromin IG 1 and Kichary IG 1 boreholes on the other (Fig. 11).

The extent of the Caledonian unconformity west of the Paleozoic core is even more speculative. There exist two Paleozoic inliers that expose the Klonów/Bostów Series and the Barcza Formation (Fig. 11). Both of them are situated in the hanging wall of the Obleggorek Fault which is the most probable western extension of the HCF. Accordingly, it may be expected that the Lower Devonian strata unconformably mantle the entire Cambrian-Silurian succession of the Łysogóry TS in that area. However, given the Late Cretaceous/Paleocene inversion of the Oblęgorek Fault (Lamarche et al., 2003), it is possible that these two outcrops occur in a footwall short-cut position. In such a case, the two Paleozoic inliers would represent slivers of the footwall rather than the hanging wall of the Variscan HCF. Hence, this evidence is not fully conclusive. The Stachura-1 borehole that hit Cambrian rocks directly below the Triassic further increases the uncertainty.

\section{AGE OF THE PROGRESSIVE UNCONFORMITY AND TIMING OF DEFORMATION}

The main progressive unconformity supported by the map pattern, and redeposition of Cambrian-Ordovician material is inferred at the base of the Klonów/Bostów Series. It constrains the timing of rotation and uplift of the southern part of the Łysogóry Region as Pridolian. More precise age assignation depends on progress in dating of the Klonów/Bostów Series, which is not straightforward (e.g., Kowalczewski et al., 1998; Malec, 2006; Kozłowski, 2008).

The postulated Pridolian deformation occurs 10 Myr prior to the beginning of the Early-Middle Pragian hiatus proposed e.g., by Malec $(2001,2006)$ and Kozłowski (2008) (Fig. 3). This hiatus is inferred to occur on the top of the Klonów/Bostów Series and not at the base of this unit. A minor unconformity in a corresponding stratigraphic position has been proposed by Kowalczewski et al. (1989, 1998), and it is sustained in this paper (Figs. 6 and 7). This may be explained in two ways:

- After the main phase of deformation in the Pridolian, rotation of the Łysogóry tilted flank resumed after $\sim 10 \mathrm{Myr}$ with similar kinematics.

- The Pragian hiatus records a more regional tectonic event related e.g., to the cessation of the Late Silurian-earliest Devonian flexural subsidence (Poprawa, 2006b).

\section{CONSEQUENCES FOR THE KINEMATICS} OF THE HOLY CROSS FAULT

The presence of the Caledonian progressive unconformity in the Łysogóry TS has consequences for the Caledonian and 
Variscan kinematics of the HCF and hence also for the palaeogeographic relationships between the Łysogóry and Małopolska blocks. Thin- and thick-skinned interpretative tectonic scenarios are presented (Fig. 12). It is proposed that these are end-members of a wide range of potential tectonic solutions.
The thin-skinned scenario assumes that thin-skinned Caledonian thrusting along the HCF was followed by Variscan reactivation with similar kinematics (Fig. 12A). The first phase of thrusting created the progressive unconformity, and the second phase folded it. The direction of fault slip offers two alternative
A Caledonian shortening

thin-skinned scenario

SSW

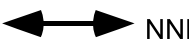

short-cut model
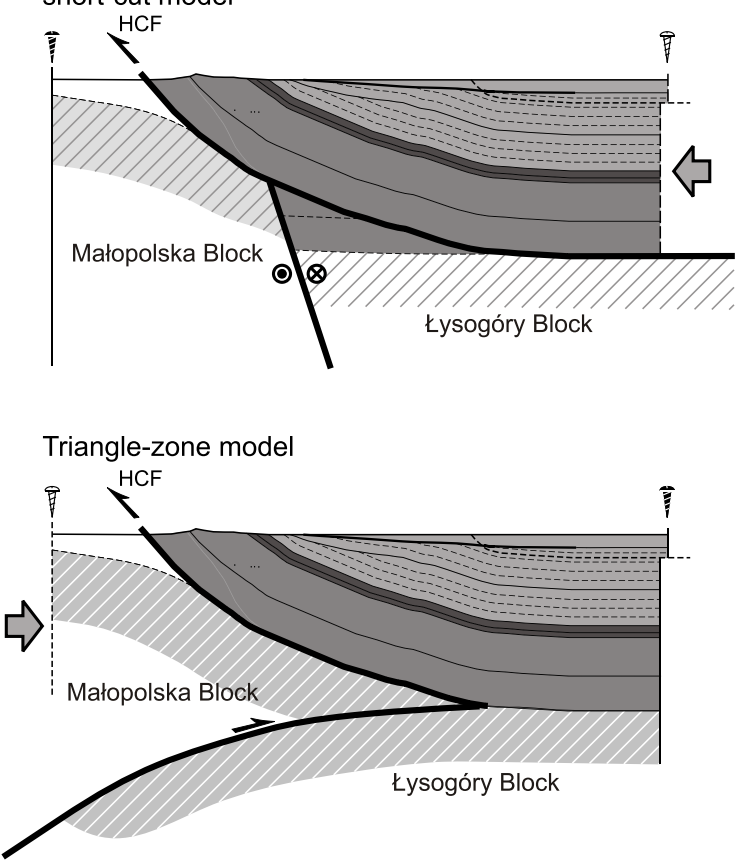

B thick-skinned scenario

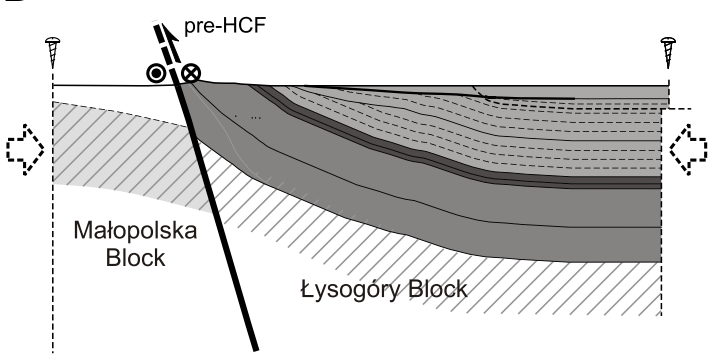

Devonian younger than the Klonów/Bostów Series

Wydryszów, Rzepin and Klonów/Bostów series

Ordovician-Lower Silurian

Post-Cambrian Paleozoic (footwall of the Holy Cross Fault only)

Mid-Upper Cambrian

common pre-Mid Cambrian substratum of the Małopolska and Łysogóry blocks (thin-skinned scenario, triangle-zone variant)

a thin-skinned scenario, short-cut variant)

Fig. 12. Kinematic interpretation of the Łysogóry Thrust Sheet based on the present and restored geometries

Thin-skinned scenario that attributes the Caledonian and Variscan deformation to repetitive activation of the HCF interpreted as a fully thin-skinned structure that soles down to the Middle Cambrian Góry Pieprzowe Fm. The "short cut" model requires the presence of a deep-rooted fault beneath the Łysogóry Thrust Sheet. The "triangle zone" model makes it unnecessary. Thick-skinned scenario that assumes a partitioning of the Caledonian and Variscan deformation between two independent structures. The Caledonian tilt is attributed to reverse slip along a thick-skinned predecessor of the HCF. The ensuing Variscan shortening activated the thin-skinned HCF that truncated the hanging wall of the pre-existing deeply rooted fault 
models for the thin-skinned scenario. In the "short-cut" model, the shortening comes from the north-northeast. In the "triangle zone" model, the shortening comes from the south-southwest. The "short-cut" model requires the preservation of a footwall shortcut at depth, which may be explained by the presence of an inherited step in the basement, possibly a pre-existing deep-rooted fault. The "triangle zone" model requires only an indentation of the leading edge of the Małopolska Block into the Middle Cambrian detachment of the Łysogóry Block.

The thick-skinned scenario assumes the interaction of two faults: a thick-skinned predecessor of the HCF, and the actual thin-skinned Variscan HCF. The Caledonian tilt is linked to reverse slip along a deeply rooted and steeply dipping fault, not exposed at present (Fig. 12B). Subsequent Variscan thrusting truncated the hanging wall of this fault along the thin-skinned HCF, resulting in the present structural pattern (Fig. 12B).

As shown by all kinematic scenarios, Variscan thrusting along the HCF is inevitable. If there was Variscan strike-slip displacement as postulated e.g., by Lamarche et al. $(1999,2003)$ and Konon (2007), it must not have been strong enough to overprint the simple geometry of the Łysogóry TS.

Both the "short-cut" model of the thin-skinned scenario and the thick-skinned scenario require a major basementrooted fault underlying the Łysogóry TS to make pre-Devonian strike-slip displacements between the Małopolska and Łysogóry blocks possible. The "short-cut" model of the thinskinned scenario would favour pre-Ordovician strike-slip movement. The thick-skinned scenario enables both pre-Ordovician and Late Silurian wrench displacements. Therefore, these two kinematic solutions may be easily integrated into the existing tectonic models (e.g., Nawrocki and Poprawa, 2006; Poprawa, 2006b; Nawrocki et al., 2007; Kozłowski, 2008; Kozłowski et al., 2014; Narkiewicz et al., 2015). They suffer however, from two limitations. First, they do not obey the Ockham's razor principle. As shown by the "triangle zone" model of the thin-skinned scenario, a deeply rooted fault is not necessary to explain the structural evolution. Second, there is a lack of any major thick-skinned faults that could displace the top-EEC basement in the deep seismic profile POLCRUST-01 (Malinowski et al., 2013). In addition, the zone of Caledonian tilt in the thick-skinned scenario is narrow, as shown by the restored cross-section C (Fig. 9). Typically, the width of the uplifted hanging wall is positively related to the depth at which a fault soles down to a detachment horizon. If the inferred Caledonian thick-skinned predecessor of the HCF had deep foundations, it would have resulted in wider uplift of the southern edge of the Łysogóry Block than is suggested by the geometry of the Caledonian unconformity.

The "triangle zone" model of the thin-skinned scenario eliminates the need for crustal-scale foundations of the HCF invoked by e.g., Brochwicz-Lewiński et al. (1984), Lewandowski (1993, 1994), Tomczykowa and Tomczyk (2000), Guterch and Grad (2006), Narkiewicz et al. (2015). Consequently, there is no way to accommodate large-scale wrenching between the Małopolska and Łysogóry blocks. This solution resolves the structural evolution of the Łysogóry TS with the minimum number of structures involved. Moreover, it may be easily integrated with the new seismic data that reveal the continuous top of the EEC basement that reaches at least up to the Małopolska Block (Malinowski et al., 2013). There are two mechanical problems inherent in the "triangle zone" model:

- It requires the preservation of a Caledonian thrust during Mid-Late Devonian extension such that it could re-activate during Variscan shortening.

- It is difficult to imagine an isolated, yet as much as $>85 \mathrm{~km}$ long, thin-skinned thrust without a strong basement control.

Moreover, the simplicity of the "triangle zone" model does not allow for Late Silurian strike-slip movement along the HCF (e.g., Nawrocki and Poprawa, 2006; Poprawa, 2006b; Nawrocki et al., 2007; Kozłowski, 2008; Kozłowski et al., 2014; Narkiewicz et al., 2015). The "triangle zone" model would therefore require a reinterpretation of the pre-Devonian tectonic evolution of the HCM.

\section{FINAL REMARKS}

Although the concept of the Caledonian unconformity in the Łysogóry Region of the Holy Cross Mts. has been repeatedly returning in several papers published over the past 40 years, it has never been commonly accepted. This idea has been deemed inconsistent with a nearly continuous and conformable Silurian-Devonian section in the Bodzentyn Syncline. This paper demonstrates that it is only an apparent discrepancy. The example of the Klonów Anticline shows that the Caledonian unconformity developed over the Łysogóry Thrust Sheet is progressive. Hence, it is the structural level at which the structure is dissected by erosion that decides whether the Devonian/Silurian contact appears conformable or unconformable.

The consequences of the proposed geometric model for the latest Silurian-earliest Devonian kinematics of the Holy Cross area are yet to be studied. It is believed that the thin- and thick-skinned kinematic scenarios are the end-members that embrace a wide range of potential solutions. These have implications for the deep crustal foundations of the Holy Cross Fault.

Acknowledgments. J.-C. Ringenbach is acknowledged for helpful comments on the early version of the manuscript. Constructive remarks by the journal reviewers S. Salwa and J. Kley are appreciated. A. Szulc is warmly thanked for his linguistic assistance. I feel indebted to R. Niedźwiedzki and A. Głuszyński for providing me remotely with old papers available only as hard copies.

\section{REFERENCES}

Belka, Z., Valverde-Vaquero, P., Dörr, W., Ahrendt, H., Wemmer, K., Franke, W., Schäfer, J., 2002. Accretion of first Gondwana-derived terranes at the margin of Baltica. Geological Society Special Publications, 201: 19-36.

Berthelsen, A., 1993. Where different geological philosophies meet: the Trans-European Suture Zone. Publications of the Institute of Geophysics, Polish Academy of Sciences, A20: 19-31.
Brochwicz-Lewiński, W., Po aryski, W., Tomczyk, H., 1984. Sinistral strike-slip movements in Central Europe in the Palaeozoic. Publications of the Institute of Geophysics, Polish Academy of Sciences, 160: 3-13.

Czarnocki, J., 1919. Stratygrafia i tektonika Gór Świetokrzyskich (in Polish). Prace Towarzystwa Naukowego Warszawskiego, 28. 
Czarnocki, J., 1936. Überblick der Stratigraphie und Paläogeographie des Unterdevons im Polnischen Mittelgebirge (in Polish with German summary). Sprawozdania Państwowego Instytutu Geologicznego, 8: 129-200.

Czarnocki, J., 1950. Geology of the Łysa Góra Region (Święty Krzy Mountains) in connection with the problem of iron ores at Rudki (in Polish with English summary). Prace Państwowego Instytutu Geologicznego, 1.

Czarnocki, J., Kuźniar, C., 1922. Les nappes de recouvrement des Montagnes de Sainte Croix (Święty Krzy) (in Polish with French summary). Sprawozdania Państwowego Instytutu Geologicznego, 1: 325-331.

Dadlez, R., Kowalczewski, Z., Znosko, J., 1994. Some key problems of the pre-Permian tectonics of Poland. Geological Quarterly, 38 (2): 169-190.

Filonowicz, P., 1969. Objaśnienia do Szczegółowej Mapy Geologicznej Polski, arkusz Bodzentyn (in Polish). Wyd. Geol., Warszawa.

Filonowicz, P., 1970. Szczegółowa Mapa Geologiczna Polski, arkusz Bodzentyn (in Polish). Wyd. Geol., Warszawa.

Filonowicz, P., 1973a. Objaśnienia do Szczegółowej Mapy Geolo gicznej Polski, arkusz Kielce (in Polish). Wyd. Geol., Warszawa.

Filonowicz, P., 1973b. Szczegółowa Mapa Geologiczna Polski, arkusz Kielce (in Polish). Wyd. Geol., Warszawa.

Ford, M., Williams, E.A., Artoni, A., Vergés, J., Hardy, S., 1997. Progressive evolution of a fault-related fold pair from growth strata geometries, Sant Llorenç de Morunys, SE Pyrenees. Journal of Structural Geology, 19: 413-441.

Gągała, Ł., 2014. On the crustal-scale triangle zone in the Holy Cross Mountains (northeastern foreland of the European Variscides). Geologia Sudetica, 42: 16-18.

Guterch, A., Grad, M., 2006. Lithospheric structure of the TESZ in Poland based on modern seismic experiments. Geological Quarterly, 50 (1): 23-32.

Konon, A., 2006. Buckle folding in the Kielce Unit, Holy Cross Mountains, central Poland. Acta Geologica Polonica, 56: 375-4405.

Konon, A., 2007. Strike-slip faulting in the Kielce Unit, Holy Cross Mountains, central Poland. Acta Geologica Polonica, 57: 415-441.

Kowalczewski, Z., Lisik, R., Chlebowski, R., 1976. New data on the geological structure of the Opatów area (in Polish with English summary). Biuletyn Instytutu Geologicznego, 296: 167-207.

Kowalczewski, Z., Kowalski, B., Janiec, J., 1989. The influence of geological structure on the sculpture of the Pasmo Klonowskie in the Góry Świętokrzyskie (in Polish with English summary). Biuletyn Państwowego Instytutu Geologicznego, 362: 65-95.

Kowalczewski, Z., Jaworowski, K., Kuleta, M., 1998. Klonów Beds (uppermost Silurian-?lowermost Devonian) and the problem of Caledonian deformations in the Holy Cross Mts. Geological Quarterly, 42 (4): 341-378.

Kozłowski, W., 2003. Age, sedimentary environment and palaeogeographical position of the Late Silurian oolitic beds in the Holy Cross Mountains (Central Poland). Acta Geologica Polonica, 53: 341-357.

Kozłowski, W., 2008. Lithostratigraphy and regional significance of the Nowa Słupia Group (Upper Silurian) of the Łysogóry Region (Holy Cross Mountains, Central Poland). Acta Geologica Polonica, 58: 43-74

Kozłowski, W., Domańska, J., Nawrocki, J., Pecskay, Z., 2004. The provenance of the Upper Silurian greywackes from the Holy Cross Mountains (Central Poland). Mineralogical Society of Poland - Special Papers, 24: 251-254.

Kozłowski, W., Domańska-Siuda, J., Nawrocki, J., 2014. Geo chemistry and petrology of the upper Silurian greywackes from the Holy Cross Mountains (Central Poland): implications for the Caledonian history of the southern part of the Trans-European Suture Region (TESZ). Geological Quarterly, 58 (2): 311-336.

Krawczyk, C.M., McCann, T., Robin, L., Cocks, M., England, R.W., McBride, J.H., Wybraniec, S., 2008. Caledonian tecton- ics. In: The Geology of Central Europe (ed. T. McCann): 303-381. The Geological Society, London.

Kroner, U., Mansy, J.-L., Mazur, S., Aleksandrowski, P., Hann, H.P., Huckriede, H., Lacquement, F., Lamarche, J., Ledru, P., Pharaoh, T.C., Zedler, H., Zeh, A., Zulauf, G., 2008. Variscan tectonics. In: The Geology of Central Europe (ed. T. McCann): 599-664. The Geological Society, London.

Kutek, J., Głazek, J., 1972. The Holy Cross Area, Central Poland in the Alpine Cycle. Acta Geologica Polonica, 22: 603-653.

Lamarche, J., Mansy, J.-L., Bergerat, F., Averbuch, O., Hakenberg, M., Lewandowski, M., Stupnicka, E., Świdrowska, J., Wajsprych, B., Wieczorek, J., 1999. Variscan tectonics in the Holy Cross Mountains (Poland) and the role of structural inheritance during Alpine tectonics. Tectonophysics, 313: 171-186.

Lamarche, J., Bergerat, F., Lewandowski, M., Mansy, J.-L. Świdrowska, J., Wieczorek, J., 2002. Variscan to Alpine heterogeneous paleostress field above a major Palaeozoic suture in the Carpathian foreland (southeastern Poland). Tectonophysics, 357: 55-80.

Lamarche, J., Lewandowski, M., Mansy, J.-L., Szulczewski, M., 2003. Partitioning pre-, syn- and post-Variscan deformation in the Holy Cross Mountains, eastern Variscan foreland. Geological Society of London, Special Publications, 208: 159-184.

Lewandowski, M., 1993. Paleomagnetism of the Paleozoic rocks of the Holy Cross Mts. (Central Poland) and the origin of the Variscan orogen. Publications of the Institute of Geophysics, Polish Academy of Sciences, 265: 1-84.

Lewandowski, M., 1994. Palaeomagnetic constraints for Variscan mobilism of the Upper Silesian and Małopolska Massifs, southern Poland. Geological Quarterly, 38 (2): 211-230.

Malec, J., 2001. Sedimentology of deposits from around the Late Caledonian unconformity in the western Holy Cross Mts. Geological Quarterly, 45 (4): 397-415.

Malec, J., 2006. Sylur w Górach Świętokrzyskich (in Polish). In: LXXVII Zjazd Naukowy PTG "Procesy i zdarzenia w historii geologicznej Gór Świętokrzyskich" (eds. S. Skompski and A. ylińska). Państwowy Instytut Geologiczny.

Malinowski, M., Guterch, A., Narkiewicz, M., Probulski, J., Maksym, A., Majdański, M., Środa, P., Czuba, W., Gaczyński, E., Grad, M., Janik, T., Jankowski, L., Adamczyk, A., 2013. Deep seismic reflection profile in Central Europe reveals complex pattern of Paleozoic and Alpine accretion at the East European Craton margin. Geophysical Research Letters, 40: 3841-3846.

Mariańczyk, J., 1973. Nowe dane o geologii regionu Bronkowic (in Polish). Przegląd Geologiczny, 21: 158-160.

Mizerski, W., 1979. Tectonic of the Łysogóry unit in the Holy Cross Mts. Acta Geologica Polonica, 29: 1-38.

Mizerski, W., 1995. Geotectonics evolution of the Holy Cross Mts. in Central Europe. Biuletyn Państwowego Instytutu Geologicznego, 372: 1-47.

Narkiewicz, M., Racki, G., Skompski, S., Szulczewski, M., 2006. Zapis procesów i zdarzeń w dewonie i karbonie Gór Świętokrzyskich (in Polish). In: LXXVII Zjazd Naukowy PTG "Procesy i zdarzenia w historii geologicznej Gór Świętokrzyskich” (eds. S. Skompski and A. ylińska). Państwowy Instytut Geologiczny.

Narkiewicz, M., Maksym, A., Malinowski, M., Grad, M., Guterch, A., Petecki, Z., Probulski, J., Janik, T., Majdański, M., Środa, P., Czuba, W., Gaczyński, E., Jankowski, L., 2015. Transcurrent nature of the Teisseyre-Tornquist Zone in Central Europe: results of the POLCRUST-01 deep reflection seismic profile. International Journal of Earth Sciences, 104: 775-796.

Nawrocki, J., 2000. Late Silurian paleomagnetic pole from the Holy Cross Mountains: constraints for the post-Caledonian tectonic activity of the Trans-European Suture Region. Earth and Planetary Science Letters, 179: 325-334.

Nawrocki, J., Poprawa, P., 2006. Development of Trans-European Suture Region in Poland: from Ediacaran rifting to Early Palaeozoic accretion. Geological Quarterly, 50 (1): 59-76.

Nawrocki, J., Dunlap, J., Pécskay, Z., Krzemiński, L., ylińska, A., Fanning, M., Kozłowski, W., Salwa, S., Szczepanik, Z., Trela, W., 2007. Late Neoproterozoic to Early Palaeozoic 
palaeogeography of the Holy Cross Mountains (Central Europe): an integrated approach. Journal of the Geological Society, 164: 405-423.

Pharaoh, T.C., 1999. Paleozoic terranes and their lithospheric boundaries within the Trans-European Suture Zone (TESZ): a review. Tectonophysics, 314: 17-41.

Poprawa, P., 2006a. Neoproterozoic break-up of the supercontinent Rodinia/Pannotia recorded by development of sedimentary basins at the western slope of Baltica (in Polish with English summary). Prace Państwowego Instytutu Geologicznego, 186: 165-188.

Poprawa, P., 2006b. Development of the Caledonian collision zone along the western margin of Baltica and its relation to the foreland basin (in Polish with English summary). Prace Państwowego Instytutu Geologicznego, 186: 189-214.

Porębska, E., 2002. Paleobiogeografia masywu małopolskiego i Łysogór w środkowym sylurze na podstawie badań graptolitów (in Polish). Przegląd Geologiczny, 50: 1220-1221.

Po aryski, W., 1990. The Middle Europe Caledonides - wrenching orogeny composed of terranes (in Polish with English summary). Przegląd Geologiczny, 38: 1-9.

Rafini, S., Mercier, E., 2002. Forward modelling of foreland basins progressive unconformities. Sedimentary Geology, 146: 75-89.

Riba, O., 1976. Syntectonic unconformities of the Alto Cardener, Spanish Pyrenees: a genetic interpretation. Sedimentary Geology, 15: 213-233.

Salwa, S., 2006. Preliminary structural-petrography characteristics of phyllite from Podmąchocice in the Łysogóry Unit of the Holy Cross Mts (in Polish with English summary). Przegląd Geologiczny, 54: 513-519.

Samsonowicz, J., 1932. Carte Géologique Générale de la Pologne au 100000 -e, feuille Opatów. Service Géologique de la Pologne.

Schätz, M., Zwing, A., Tait, J., Bełka, Z., Soffel, H.C., Bachtadse, V., 2006. Paleomagnetism of Ordovician carbonate rocks from Małopolska Massif, Holy Cross Mountains, SE Poland -
Magnetostratigraphic and geotectonic implications. Earth and Planetary Science Letters, 244: 349-360.

Stupnicka, E., 1988. On the nature and origin of the Holy Cross Dislocation (in Polish with English summary). Przegląd Geologiczny, 36: 40-46.

Suppe, J., 1983. Geometry and kinematics of fault-bend folding. American Journal of Science, 283: 648-721.

Suppe, J., Sàbat, F., Muñoz, J.A., Poblet, J., Roca, E., Vergés, J., 1997. Bed-by-bed fold growth by kink-band migration: Sant Llorenç de Morunys, eastern Pyrenees. Journal of Structural Geology, 19: 443-461.

TSCreator visualization of enhanced Geologic Time Scale 2004 database, Version 6.3, 2015. James Ogg (database coordinator) and Adam Lugowski (software developer) http://www.tscreator.org

Tokarski, A., 1958. Notes on structure types in the Metha-Carpathian Arch (in Polish with English summary). Geological Quarterly, 2 (4): 807-824.

Tomczykowa, E., Tomczyk, H., 2000. The Lower Palaeozoic in the Daromin IG 1 borehole - confirmation of the concept of the terrane structure of the Łysogóry and Małopolska blocks (Góry Świętokrzyskie Mts.). Biuletyn Państwowego Instytutu Geologicznego, 393: 9-15.

Williams, E.A., Ford, M., Vergés, J., Artoni, A., 1998. Alluvial gravel sedimentation in a contractional growth fold setting, Sant Llorenç de Morunys, southeastern Pyreees. Geological Society Special Publications, 134: 69-106.

Znosko, J., 1996. Tectonic style of the Early Palaeozoic sequences in the Holy Cross Mountains. Geological Quarterly, 40 (1): 1-22.

elaźniewicz, A., 1998. Rodinian-Baltican link of the Neoproterozoic orogen in southern Poland. Acta Universitatis Carolinae, Gologica, 42: 509-515.

ylińska, A., Masiak, M., 2007. Cambrian trilobites from Brzechów, Holy Cross Mountains (Poland) and their significance in stratigraphic correlation and biogeographic reconstructions. Geological Magazine, 144: 661-686. 